University of Vermont

UVM ScholarWorks

2-7-2018

\title{
Mixed methods approach to understanding farmer and agricultural advisor perceptions of climate change and adaptation in Vermont, United States
}

\author{
Rachel E. Schattman \\ University of Vermont \\ V. Ernesto Méndez \\ University of Vermont \\ Scott C. Merrill \\ University of Vermont \\ Asim Zia \\ University of Vermont
}

Follow this and additional works at: https://scholarworks.uvm.edu/calsfac

Part of the Agriculture Commons, Climate Commons, and the Sustainability Commons

\section{Recommended Citation}

Schattman RE, Méndez VE, Merrill SC, Zia A. Mixed methods approach to understanding farmer and agricultural advisor perceptions of climate change and adaptation in Vermont, United States. Agroecology and Sustainable Food Systems. 2018 Feb 7;42(2):121-48.

This Article is brought to you for free and open access by the College of Agriculture and Life Sciences at UVM ScholarWorks. It has been accepted for inclusion in College of Agriculture and Life Sciences Faculty Publications by an authorized administrator of UVM ScholarWorks. For more information, please contact scholarworks@uvm.edu. 


\title{
Agroecology and Sustainable Food Systems
}

ISSN: 2168-3565 (Print) 2168-3573 (Online) Journal homepage: https://www.tandfonline.com/loi/wjsa21

\section{Mixed methods approach to understanding farmer and agricultural advisor perceptions of climate change and adaptation in Vermont, United States}

\author{
Rachel E. Schattman, V. Ernesto Méndez, Scott C. Merrill \& Asim Zia
}

To cite this article: Rachel E. Schattman, V. Ernesto Méndez, Scott C. Merrill \& Asim Zia (2018) Mixed methods approach to understanding farmer and agricultural advisor perceptions of climate change and adaptation in Vermont, United States, Agroecology and Sustainable Food Systems, 42:2, 121-148, DOI: $10.1080 / 21683565.2017 .1357667$

To link to this article: https://doi.org/10.1080/21683565.2017.1357667

View supplementary material $₫$

Submit your article to this journal $\longleftarrow$

凹 Article views: 567

Q View related articles ๔

View Crossmark data $\widetilde{ }$

Co

Citing articles: 8 View citing articles $\square$ 


\title{
Mixed methods approach to understanding farmer and agricultural advisor perceptions of climate change and adaptation in Vermont, United States
}

\author{
Rachel E. Schattman (10) ${ }^{a}$, V. Ernesto Méndez ${ }^{b}$, Scott C. Merrillc, and Asim Zia ${ }^{d}$ \\ annited States Department of Agriculture, Forest Service, Northeast Climate Hub, University of \\ Vermont, Burlington, VT, USA; ${ }^{b}$ Department of Plant and Soil Science, Agroecology and Livelihoods \\ Collaborative, University of Vermont, Burlington, VT, USA; 'Department of Plant and Soil Science, \\ University of Vermont, Burlington, VT, USA; ${ }^{d}$ Department of Community Development and Applied \\ Economics, University of Vermont, Burlington, VT, USA
}

\begin{abstract}
The relationships among farmers' belief in climate change, perceptions of climate-related risk, and use of climate adaptation practices is a growing topic of interest in U.S. scholarship. The northeast region is not well represented in the literature, although it is highly agricultural and will likely face climaterelated risks that differ from those faced in other regions. We used a mixed methods approach to examine northeast farmers' perceptions of climate change and climate-related risks over time, and perceived trade-offs associated with on-farm practices. Our investigation shows how northeastern farmers think about climate-risk, and what they are doing to address it.
\end{abstract}

\section{KEYWORDS}

Agriculture; agroecology; best management practices; climate change; risk

\section{Introduction}

It is well established that climate change will have significant impact on agroecological food systems ${ }^{1}$ in the coming decades and centuries. Reduction in agricultural productivity due to degradation of soil and shifts in water resources is expected to occur at an accelerated rate in the next 25 years, which will likely lead to changes in land use and land cover. In the northeastern United States, increasing average temperatures and rainfall, increasing pest and disease pressure, and more frequent incidents of extreme weather events are anticipated (Frumhoff et al. 2007; Horton et al. 2014; Tobin et al. 2015; Walthall et al. 2012). While many parts of the country are expected to become hotter and drier, this region is projected to experience an increase in the intensity and frequency of heavy downpours in coming decades (Guilbert et al. 2015). A 71\% increase in very heavy precipitation

CONTACT Rachel E. Schattman rschattman@fs.fed.us $\Theta$ United States Department of Agriculture, Forest Service, Northeast Climate Hub, University of Vermont, 231 Jeffords Hall, Carrigan Drive, Burlington, VT 05405, USA.

Color versions of one or more of the figures in the article can be found online at www.tandfonline.com/WJSA.

(4) Supplemental data for this article can be accessed on the publisher's website.

${ }^{1}$ In this manuscript, we use the following definition of agroecological food systems: food systems that adequately manage and conserve ecological processes are socially just and economically viable (Gliessman 2015). 
(the heaviest $1 \%$ of all daily rain events) since 1958 has already been documented (Walsh, Wuebbles, and Hayhoe 2014). Increasingly high water tables, soil saturation, increased base flow in streams (Weider and Boutt 2010), as well as heavy downpours and extended periods of rainfall have led to increased flooding, the greatest weather-related risk in some of the region's inland areas (Kunkel et al. 2013). Despite this notable difference between the northeast and other areas of the United States, research on agricultural stakeholder perceptions of climate change and capacity for climate change adaptation in this region is underrepresented (Chatrchyan et al. 2017).

Changes in average and extreme temperature and humidity, as well as rising levels of $\mathrm{CO}_{2}$ and tropospheric ozone will affect complex ecological communities of plants, insects, and other species that interact with agricultural systems (Fuhrer 2003). It is likely that productivity will drop due to increasing pressure from plant diseases, even as the number of annual frostfree growing days increases in number. Increasing rainfall, increasing temperatures, and greater temperature variability can delay plantings in the spring, challenging both crop and livestock health and productivity (Betts 2011; Frumhoff et al. 2007; Galford et al. 2014; Horton et al. 2014). Farm management strategies that potentially limit the negative impacts of climate change on farms in the northeastern United States overlap with conservation best management practices (BMPs) such as cover cropping, reduced tillage, and storm water runoff management. Agricultural management of soil loss, soil health, and nutrient runoff is not new, but takes on heightened importance as the likelihood and frequency of intense rainfall, flooding, or sustained dry and wet periods in this region increases (Horton et al. 2014). These practices, when they contribute to adaptation of individual farm businesses, are necessarily located within a larger social framework (Casanova-Pérez et al. 2016) that includes institutional constraints, regulations, and social norms (as described by Adger et al. 2005), and are influenced by farmers' climate change beliefs, their perceptions of risk, and attitudes.

The state of Vermont, where this case study was conducted, is home to a diversity of agricultural sectors including dairy, meat, vegetable, and highly diversified operations (USDA-NASS 2013). Compared with the United States as a whole, farms in the northeast tend to be smaller and more diversified. The highest percentage (31\%) of Vermont farms are between 10 to 49 acres, with an average farm size of 171 acres. For comparison, the national average farm size is 234 acres (Macdonald, Korb, and Hoppe 2013). Producers of agricultural products in this area and elsewhere in the country have long employed conservation BMPs to address financial, ecological, and social risk to their businesses and their livelihoods (Baumgart-Getz, Prokopy, and Floress 2012). Conservation BMPs that are relevant to Vermont and the 
broader northeast region include those that help farmers address erosion from precipitation, nutrient management, and soil health. However, it is unknown if current conservation BMPs are the practices that can best protect farmers from the intensifying risks associated with a changing climate, or if they adequately address additional climate-related concerns, such as pest and diseases. Additionally, it is unclear how farmer climate change beliefs and their perceptions of associated risks play into their decisions to adopt either incremental or transformative adaptation strategies.

Considering this, we sought to answer the following research questions:

(1) What percentage of Vermont farmers believe in climate change? This is a relevant question considering recent literature that shows that belief in climate change varies across groups of farmers. These investigations have examined how belief in climate change, belief in anthropogenic climate change and climate skepticism are viewpoints represented among farmers and agricultural advisors (Prokopy et al., 2015b), and how the level of belief is tied to climate-related behavior (Niles and Mueller 2016). Based on previous surveys of climate change beliefs conducted with U.S. citizens (Howe et al. 2015) and farmers in the United States and other high-income countries (Prokopy et al., 2015a), we hypothesize $\left(\mathrm{H}_{1}\right)$ that the majority of Vermont farmers believe in climate change and that this percentage is higher than the national average.

(2) Do farmers in Vermont perceive climate change and associated impacts as risks to their farms? Climate change risk perceptions have been highlighted as a central aspect to predicting adaptation potential in agricultural communities (Eakin et al. 2016). By asking farmers to forecast how these climate pressures (specific to the northeastern United States) will affect their farms, we can better understand farmers' level of concern, which impacts are more worrisome to them, and what adaptation strategies may work for them in the future. Of the farmers that believe in climate change, we hypothesize that $60 \%$ do not believe that climate change will directly and negatively affect their farms $\left(\mathrm{H}_{2 \mathrm{a}}\right)$. We also hypothesize $\left(\mathrm{H}_{2 \mathrm{~b}}\right)$ that fewer farmers will perceive these risks as relevant to their farms than the percentage of farmers that believe in climate change. This is informed by research that shows that while many U.S. citizens believe in climate change, a smaller percentage believe that it will negatively impact them personally (Leiserowitz et al. 2015).

(3) Do farmers' beliefs about climate change or their perception of climaterelated risk change over time? Few surveys for farmer climate belief and perceptions of risk are longitudinal in nature. It has been suggested that personal experience with extreme weather or other climate-related impacts has an influence on farmers' perceptions of risk, but not on their belief in climate change itself (Carlton et al. 2016). Prior to our study, this has not 
been tested with farmers in the northeastern United States. We hypothesize that $\left(\mathrm{H}_{3 \mathrm{a}}\right)$ farmers' beliefs about climate change will remain steady over time, but $\left(\mathrm{H}_{3 \mathrm{~b}}\right)$ their perceptions of climate-related risks will be influenced by recent extreme weather events.

(4) Which BMPs do farmers and agricultural advisors perceive as the most useful in a climate change context? There are a large number of practices that could potentially help farmers adapt to a changing climate, but little information on how well these practices may perform in the future, under projected climate change conditions. We use the applied knowledge and experience of farmers and agricultural advisors to inform future evaluation of a subset of these practices through on-farm trials or other approaches.

(5) Are farmers and agricultural advisors in agreement about the utility of BMPs in the context of climate change? By exploring similarities between farmer and agricultural advisor perceptions of BMPs, we can better plan for climate-related outreach and education for these two important groups. Considering the important role that agricultural advisors serve in communicating climate science to farmers, few studies have focused on advisors' perceptions and beliefs about climate change (with research conducted in the midwestern United States, such as Haigh et al. (2015) and Carlton et al. (2016) as notable exceptions).

\section{Background}

\subsection{Study site}

The northeastern United States is a diverse region with many agricultural sectors represented within it. The dairy industry accounts for a significant portion of agriculture in the region, accounting for $\$ 5.5$ billion in gross sales from over 14,000 operations (USDA-NASS 2012). Two states, Pennsylvania and New York, account for $80 \%$ of dairy, $43 \%$ of vegetable, and $40 \%$ of fruit/ tree nuts/berry gross receipts (USDA-NASS 2012). Four northeastern states (New York, Pennsylvania, Vermont, and Maine) are among the top 10 in the country when it comes to the number of organic farms, and two (New York and Pennsylvania) rank in the top 10 states in the country for annual sales of organic agricultural products (New York $=\$ 165$ billion, Pennsylvania $=\$ 313$ billion) (USDA-NASS 2015). The region is highly forested, with over 85 million acres in forest land (61\% of the region), which is estimated to contribute over $\$ 25.5$ billion in economic impact to the United States (Lopez et al. 2015). The wooded and mountainous terrain of the northeast influences the types of agriculture that can be practiced there. Compared with other regions of the country, farms are typically small in size.

Vermont, where we conducted our investigation, is a small state within the northeast. It has a diverse array of agricultural businesses within it, including dairy, timber, vegetable, tree fruit, berries, hay, and fiber crops; meat, and egg production, in addition to many specialty crops. It is estimated that the 
agricultural sector (including processing of agricultural products) provides a little over 29,000 jobs. The total state population was 624,594 in 2016 (Lopez et al. 2015; United States Census Bureau 2017). According to the USDA, 50\% of Vermont farmers (principal operators) work off-farm in addition to their agricultural activities - for at least a portion of the year. The average age of Vermont farmers (57 years old) has steadily risen over several decades, as is the case in most regions of the United States. However, recent years have brought an uptick in beginning farmers, especially between the 2002 and 2012 census (USDA-NASS 2012). According to the National Sustainable Agriculture Coalition (2014), the state of Vermont led the nation in the percentage growth of new and beginning farmers in the years 2007-2012.

\subsection{Climate adaptation}

It is clear that, in order to continue functioning, agroecological food systems must adapt to climate change. Climate change adaptation is defined as the "adjustment in natural or human systems in response to actual or expected climatic stimuli or their effects, which moderates harm or exploits beneficial opportunities" (IPCC 2007, 869). Adaptation can be applied to a wide array of highly context-specific goals (Risbey et al. 1999), with the limitations of adaptation being highly dependent on culture, ethics, perception of risk, and knowledge (Adger et al. 2008). Farmers may employ adaptation practices explicitly to adapt to changing climatic conditions and weather patterns, or may alternatively (or simultaneously) be motivated by other values and goals. The direct function of adaptation is the reduction in vulnerability (Brooks 2003), which Adger (2006) defines as "the state of susceptibility to harm from exposure to stresses associated with environmental and social change and from the absence of capacity to adapt" $(2006,268)$. In order to increase the use and efficacy of BMPs, specifically those that support climate change adaptation, we must understand why farmers are or are not motivated to adopt them.

Attempts to understand motivation behind adoption decisions have been ongoing since the 1950s. Early examinations look at the issue from a variety of angles, including the adoption of specific practices such as farmer decisions to use fertilizer (Williams 1958); the importance of personal and social influences on agricultural adoption of new technologies (Rogers and Beal 1957); and adoption as conceptual, progressive, and internal models of change (Hassinger 1959). Recent studies that look at farmer motivation for addressing soil health practices show that farmers face agronomic, policy, financial, and knowledge barriers to adoption of BMPs (Carlisle 2016). This reinforces findings in Baumgart-Getz, Prokopy, and Floress' (2012) metaanalysis of 46 studies from the United States, which showed that the following 3 factors significantly influence the willingness of contemporary farmers 
to adopt BMPs: (a) access to and quality of information, (b) financial capacity, and (c) social or professional connections to an agency, local networks of farmers, or other associations such as regional watershed groups. Alternative approaches to understanding decision-making processes, specifically related to climate adaptation practices, integrate social and psychological factors. This is appropriate and necessary because climate change, and by extension the role that climate change plays in on-farm decision-making, is a highly contentious and divisive issue in the United States. An individual's belief in climate change (or lack thereof) has been shown to be influenced by social factors that are not directly linked to the act of farming, including political affiliation (Dunlap, McCright, and Yarosh 2016; Schuldt, Konrath, and Schwarz 2011; Wiest, Raymond, and Clawson 2015), perceived adaptive capacity (Singh, Dorward, and Osbahr 2016), and perception of self (i.e., identity) (Morton, McGuire, and Cast 2016). Therefore, integration of social and psychological frameworks is essential to fully understand the complexity of factors that affect farmer's responses to climate change.

Attempts to document farmers' belief or lack of belief in climate change and its causes are driven, in part, by a shared desire to understand how social and psychological factors (e.g., belief systems) influence behavior. Geographically discrete examples of these studies include Barnes and Toma (2012) in Scotland, Arbuckle et al. (2013) in Iowa (USA), Hyland et al. (2016) in Wales, and Niles, Lubell, and Haden et al. (2013) in California (USA). These studies sometimes present alternative views on whether producers' willingness to adopt BMPs specifically for climate change adaptation purposes is influenced by their belief in climate change, their perceptions of climate-related risk, or first-hand experience with extreme events (Akerlof et al. 2013; Brody and Zahran 2008; Carlton et al. 2016; Mase, Gramig, and Prokopy 2016; Roesch-McNally, Arbuckle, and Tyndall 2017; Spence et al. 2011). Challenging the idea that a single sociopsychological factor is the best predictor of farmers' intention to adopt climate change adaption practices, Van Der Linden (2014) finds that climate belief, risk perception, and firsthand experience influence one another, and that personal experience with climate change, affect, and risk perception are tightly tied together in feedback loops. This finding is confirmed by Myers et al. (2013), who show that individuals both understand their exposure to observable climate impacts through the lens of their belief in climate change, and that beliefs about climate change are influenced by exposure to observable climate impacts. It is possible that belief in climate change and/or perceived climate-related risk not only influence farmer decisions to implement a BMP or not, but also affect the way in which they chose to implement a BMP. For example, a 10' riparian buffer strip may be a sufficient approach to limiting sediment erosion under normal conditions, but a farmer may put in place a much wider buffer if they consider increased frequency of severe floods. It is 
unclear if all farmers using BMPs implement them to the degree necessary to protect them from climate change impacts. BMP adoption by farmers who do not accurately anticipate the severity of future climate change impacts may choose to under-scale practices.

Agricultural advisors, many of whom have the responsibility to provide farmers with information and resources, have an important role to play in helping farmers protect themselves from potential negative impacts from our changing climate. Considering this, agricultural advisors need to be aware of the social and psychological factors that influence a farmers' engagement with climate change topics as well as their decision to engage in climate adaptation activities.

Access to information about climate change and the ability to derive value from that information have been established as critical factors in management of agricultural risk (Just, Wolf, and Zilberman 2003). Despite this need for artful integration of climate information into traditional outreach and education, Haigh et al. (2015) demonstrate that not all agricultural advisors include climate change information in their outreach and education efforts. Their study in four states of the midwestern United States shows that agricultural advisors who deliver agronomic and/or conservation support to farmers are willing to support climate change work, but agricultural advisors who provide financial planning support are willing to address the issue to a much lesser degree. Advisors' reticence to integrate climate information into their outreach could be influenced by their own belief about climate change and/or willingness to rely on long-term forecasts (Prokopy et al. 2013), a belief that language that includes climate change could be a barrier to working with farmers (Arbuckle et al. 2014), or a perception that climate change is not relevant to their expertise. Which of these factors has the greatest influence is unknown. There have been comparatively few studies that focus on the belief in climate change held by agricultural advisors, or how these impacts, risks, and adaptation may influence farm viability in the future (Mase and Prokopy 2013).

\section{Methods}

This research was conducted as part of a larger, transdisciplinary research and outreach effort referred to as the "Vermont Agricultural Resilience in a Changing Climate Initiative: (VAR), initiated in 2011 at the University of Vermont (UVM). In this case study, we report on results from two research efforts that were executed under the umbrella of the VAR initiative: (1) a two-part, longitudinal survey of farmers in two watersheds in the state of Vermont, USA, conducted in 2013 and 2016; and (2) semi-structured interviews conducted with farmers and agricultural advisors in that same region 
in 2013-2014. For an overview of the transdisciplinary and participatory approach of the VAR initiative, see Schattman et al. (2015b).

The two-part survey was sponsored by the VAR team (in 2013) and, in 2016, by the Research on Adaptation to Climate Change in the Lake Champlain Basin (RACC) project, which was funded by the Vermont EPSCoR program. Both deployments of the survey were targeted toward farmers in the Lamoille and Missisquoi watersheds, located in the Champlain Valley of Vermont. To ensure our survey was delivered to all eligible farmers within the specified watersheds, both VAR and RACC contracted with the National Agriculture Statistics Service (NASS).

The survey instrument was tested with five farmers in 2011, and revised to incorporate their feedback. There were also revisions made between the two deployments of the survey, though effort was made to ensure that most questions were repeated with no adjustments. We adopted a two-step approach to establish our target population for the survey, as follows. First, NASS, using a census approach, compiled a list of all agricultural landowners in zip codes within the two target watersheds. Second, in the winter of 2012, 1,104 postcards were sent to these agricultural landowners. The purpose of the postcard was to determine whether the respondent was eligible to receive our survey, based on gross farm sales in 2013. We received replies from $20 \%$ of these landowners. Of those who replied, 128 matched eligibility requirements, and as such were established as our target population. The full survey questionnaire was mailed to the target population between April and July 2013. Of these, 48 complete surveys were returned in the mail by the respondents, and 30 were collected over the phone by NASS enumerators, for a total of 78 complete responses (61\% response rate, a 6.96 confidence interval at a 95\% confidence level). In 2016, NASS identified 180 target respondents in the same watersheds, trained enumerators and began data collection for the second survey deployment in March, which was concluded at the end of June. A total of 138 farmers were contacted by phone, of which 112 responded to the survey via personal interview ( $81 \%$ response rate, a 4.03 confidence interval at a 95\% confidence level), including 56 farmers who responded to the 2013 survey. Of the 26 farmers who declined to respond to the survey, 5 had previously responded to the 2011 survey.

Survey values were weighted to make the responses representative of the distribution of farm types observed in the entire state of Vermont. We used the United States Department of Agriculture (USDA) 2007 Census to weight the sample for the 2013 survey, and the 2012 Census to weight the sample for the 2016 survey, based on an average value derived from distribution of farm size (small, medium, and large) and management approach (conventional or organic). A final weight was calculated by taking the arithmetic mean of sampling weight by farm size and farm management type for the sampled farm. This weighting procedure was necessary because our survey population 
was less representative of small farms and overly representative of medium farms in both years. Similarly, conventional farms in our sample were slightly under-represented, while organic farms were over-represented in both years. By weighting the responses to our survey, we sought to make the results reflect characteristics of the general farming population in Vermont. Yet, we encourage readers to interpret our results as indicative of the opinions and beliefs of our survey respondents, and not the broader population of Vermont farmers, given that our methodology captured beliefs from a relatively small proportion of the Vermont farmer population. A table describing our weighing procedure is included in our supplemental material (Table S1), as is a series of unweighted demographic description tables (Table S2), and both survey instruments (the 2013 survey can be found in S1 Text, the 2016 survey in S2 Text).

To investigate change in farmer belief in climate change and perception of climate risk over time, we paired responses from the 56 farmers who responded to both the 2013 and 2016 surveys. In response to two questions ("In your opinion, is the climate changing?" and "If you believe the climate is changing, do you believe this will affect your farm in a negative way?") respondent answers were coded into binary codes $(1=$ yes, $0=$ no/not sure). A McNemar, nonparametric, test was conducted to determine if there was a statistically significant change over time in (a) the proportion of farmers who believed in climate change, or (b) the proportion of farmers who believed climate change posed a significant risk to their farm. Three additional questions addressed specific climate-related risks relevant to the northeastern United States, including heavy rain events, increasing extreme temperatures, and drought. Respondents reported whether they believed each risk would have a strongly positive, positive, neutral, negative, or strongly negative impact on their farm. Three Wilcoxon signed ranks tests were performed to test whether farmer perceptions of each of the climate-related risks changed between the two surveys. Statistical analyses were conducted using SPSS, version 23 (IBM 2012).

Following the 2013 survey, interviews were held with 15 farmers (on-farm) and 12 agricultural advisors (business consultants, state agency representatives, programming staff, etc.) in 2013-2014. We selected and recruited farmers for these interviews through organizational key contacts and survey responses. Farmers were approached to participate in an interview if: (1) they responded as willing in the survey described above, (2) they met minimum gross agricultural income requirements of $\$ 10,000$ or more in 2011, and (3) they were implementing a subset of BMPs appropriate for later stages of investigation by our team. These practices were no-till cultivation, cover cropping, storm water runoff management, rotational grazing, and the use of conservation buffers. The last criterion was included because many farmers participated in a range of research activities across the transdisciplinary 
effort. The farmers interviewed included dairy $(n=5)$, vegetable $(n=4)$, meat $(n=1)$, and highly diversified farmers $(n=5)$.

Agricultural advisors interview participants were identified through their affiliation with organizations in Vermont that deliver advising services to the agricultural community. We sought to solicit individuals who worked with farmers in a wide range of capacities, and with a diversity of production groups. Agricultural advisor participants were employed by state (Vermont Agency of Agriculture Food and Markets, the Vermont State Climate Office) and federal agencies (the National Resource Conservation Service), several different programs within University of Vermont Extension, nonprofit organizations, as well as independent consultants.

Interviews lasted between 1 and $1.5 \mathrm{~h}$, and were recorded using a digital recorder. The conversations were transcribed and analyzed using HyperResearch (Researchware, Inc., 2013). During the interviews, we used an evaluation tool developed by Lovell et al. (2010) to investigate farmer perceptions of multifunctional landscapes. This tool is included in our supplemental material (Table S3), as are both interview instruments (S3Text and S4Text). We adapted the tool to evaluate potential of on-farm climate adaptation BMPs, and asked farmers to select 3 or 4 practices from a list of 20 that they felt the most experienced with. We also invited them to add a potential climate adaptation BMP, if they felt that an important practice had been left off the list. The original list of potential climate change adaptation BMPs was developed from a review of literature related to conservation BMPs, specifically those with potential to limit a farmer's climateor weather-related risk. Two additional potential climate adaptation BMPs were added by interview participants (these can be seen in Table 1). Readers should note that some BMPs were not evaluated by all of the participants. This is because we sought farmers and agricultural advisors from diverse sectors, and many BMPs were relevant to only a subset of our participants. The categories used to evaluate the practices (e.g., financial, ecological, and sociocultural) are based upon the premise put forward by Francis et al., which calls for an interdisciplinary approach to the "ecology of food systems" $(2003,100)$. Attributes of potential climate adaptation BMPs within these broad categories were identified and vetted by our multidisciplinary research team, and are relevant to those climate change challenges specific to northeastern U.S. agriculture (for a complete list of attributes used, see Table 2).

Interview participants were asked to select a few potential climate adaptation BMPs based on their familiarity and experience with those practices. Participants scored each attribute for the potential climate adaptation BMPs on $a-2$ to +2 scale. Negative rankings indicated that the interview participant perceived that the potential climate adaptation BMP had a negative impact on the attribute in question, while positive rankings indicated a positive impact. A score of zero indicated a neutral impact, or a lack of knowledge on the part of the 
Table 1. Potential climate adaptation practices and number of interview participants who evaluated each practice.

\begin{tabular}{|c|c|c|c|}
\hline Best management practice & $\begin{array}{l}\text { Farmers } \\
(n=15)\end{array}$ & $\begin{array}{c}\text { Agricultural } \\
\text { advisors }(n=12)\end{array}$ & $\begin{array}{c}\text { Total } \\
(N=27)\end{array}$ \\
\hline Hoop houses/high tunnels & 8 & 4 & 12 \\
\hline Green manure (crop residue incorporation into soil) & 3 & 2 & 5 \\
\hline Cover crops & 7 & 4 & 11 \\
\hline Reduced tillage (zone, strip, key-line plowing, deep tillage) & 1 & 3 & 4 \\
\hline No till & 0 & 2 & 2 \\
\hline Timely manure incorporation & 1 & 1 & 2 \\
\hline Pest/disease management & 4 & 1 & 5 \\
\hline Invasive species management & 2 & 0 & 2 \\
\hline Irrigation (automated, drip, overhead) & 2 & 1 & 3 \\
\hline Storm water runoff management & 3 & 2 & 5 \\
\hline Wetland conservation & 1 & 2 & 3 \\
\hline Nutrient management plans (any, not just government approved) & 0 & 1 & 1 \\
\hline $\begin{array}{l}\text { Conservation buffer strips (riparian buffers, wind breaks, } \\
\text { stream corridors, buffer strips, shelter belts, hedgerows) }\end{array}$ & 1 & 3 & 4 \\
\hline Drainage tile & 0 & 0 & 0 \\
\hline Rotational grazing & 9 & 3 & 12 \\
\hline Animal diversity & 3 & 0 & 3 \\
\hline Animal feed management & 5 & 0 & 5 \\
\hline Agroforestry (silvo-pasture, alley cropping, forest farming) & 0 & 0 & 0 \\
\hline Alternative energy (biomass, wind, solar, methane digesters) & 1 & 1 & 2 \\
\hline Insurance (farm policies, crop insurance, product liability) & 3 & 1 & 4 \\
\hline Financial analysis/planning ${ }^{a}$ & 0 & 1 & 1 \\
\hline Soil health/soil quality ${ }^{\mathrm{a}}$ & 0 & 1 & 1 \\
\hline
\end{tabular}

${ }^{\text {a }}$ Practices added by interview participants, not on original list of BMPs and therefore not available to all participants at the time of the interview.

Table 2. Attribute categories and attributes of potential climate adaptation BMPs.

\begin{tabular}{|c|c|c|}
\hline Attribute category 1: Financial & Attribute category 2: Ecological & $\begin{array}{c}\text { Attribute category } 3: \\
\text { Sociocultural }\end{array}$ \\
\hline $\begin{array}{l}\text { - Production/yield } \\
\text { - Alignment of supply and demand (timing, } \\
\text { variety, and/or volume) } \\
\text { - Diversification of products } \\
\text { - Product quality } \\
\text { - Efficiency of consumable inputs } \\
\text { - Efficiency of capital investments } \\
\text { - Efficiency of farmer's labor } \\
\text { - Efficiency of hired labor } \\
\text { - Marketing potential }\end{array}$ & $\begin{array}{l}\text { - Impact on biodiversity } \\
\text { - } \text { - Management of excess } \\
\text { water (rain, flood) } \\
\text { - Protection of water quality } \\
\text { - Chemical application impact } \\
\text { - Greenhouse gas } \\
\text { - } \text { sequestration } \\
\text { - } \text { - Impail conservation/building } \\
\text { - } \text { the landscape } \\
\text { - Response to changing } \\
\text { - } \text { extreme temperatures } \\
\text { - } \text { age temponse to changing aver- } \\
\text { Impact on fuel usage/ } \\
\text { emissions }\end{array}$ & $\begin{array}{l}\text { - } \text { Protection of worker } \\
\text { - } \text { Impalth } \\
\text { relations } \\
\text { - Landscape appearance } \\
\text { - Acceptability to } \\
\text { - } \text { customers } \\
\text { - } \text { Acceptability to peers } \\
\text { cultural land use }\end{array}$ \\
\hline
\end{tabular}

interview participant. Because of the amount of time that this exercise required, participants selected only between three and five practices with which to engage in the activity. This does not mean that they did not use the other practices 
included in the study. Attribute scores were combined, and weighted to account for a different number of respondents for each BMP. The weighted score of each practice was standardized to range between -1 and 1 . We compiled results for farmers, agricultural advisors, and a combined score for each practice in financial, ecological, and sociocultural categories. This allowed us to compare potential climate adaptation BMP scores to one another, and identify those that stood out as being key adaptation approaches according to farmers and agricultural advisors. It also allowed us to observe differences between how the perceptions of these two types of informants differed. We assessed differences through $F$-tests to compare variance between the two groups, and independent $t$-tests to determine if potential climate adaptation BMP rankings differed significantly. We analyzed only those practices evaluated by more than one farmer and agricultural advisor. In addition, we used interview transcripts to provide deeper meaning to results from the potential climate adaptation BMP evaluation scores. To ensure the reliability of our qualitative analysis, two researchers coded the interview transcripts independently. The researchers met frequently to compare notes, discuss alignment, discrepancy of interpretations, and results. This approach, called the constant comparison approach to analysis, allowed us to look for broad emergent themes from the interviews (Boeije 2002; Charmaz 2005; Glaser and Strauss 1967; Strauss and Corbin 1990).

\section{Results}

\subsection{Survey results}

In both years, the majority of farmers who participated in the survey reported that they believe in climate change (78\% in 2013 and $82 \%$ in 2016). Many respondents also believe that climate change will affect their farms in a negative way (47\% in 2013 and $46 \%$ in 2016). Equally of interest is the size of the respondent group in both years $(25 \%$ in 2013 and $28 \%$ in 2016) who reported being unsure if a changing climate would have negative effects on their farms (Figure 1). Few survey respondents believed that heavy rain events, increasing extreme temperatures, or droughts would benefit their farm operations $(<4 \%$ in both survey years). The majority of respondents believed that they would see negative or strongly negative net impacts on their farms (Figure 2). There was an important group who reported being unsure of how they will be impacted by the risks (between $6 \%$ and $13 \%$ of farmer respondents depending on the climate-related pressure in question).

By deploying our survey two times, three years apart, we were able to investigate changes in farmers' perceived sensitivity to risk. McNemar tests showed that the majority of the 56 farmers who responded to the survey in both years reported consistently held beliefs that climate change is occurring $(88 \%, n=56)$, and that climate change will negatively impact their farm 
Is the climate changing? (2013)

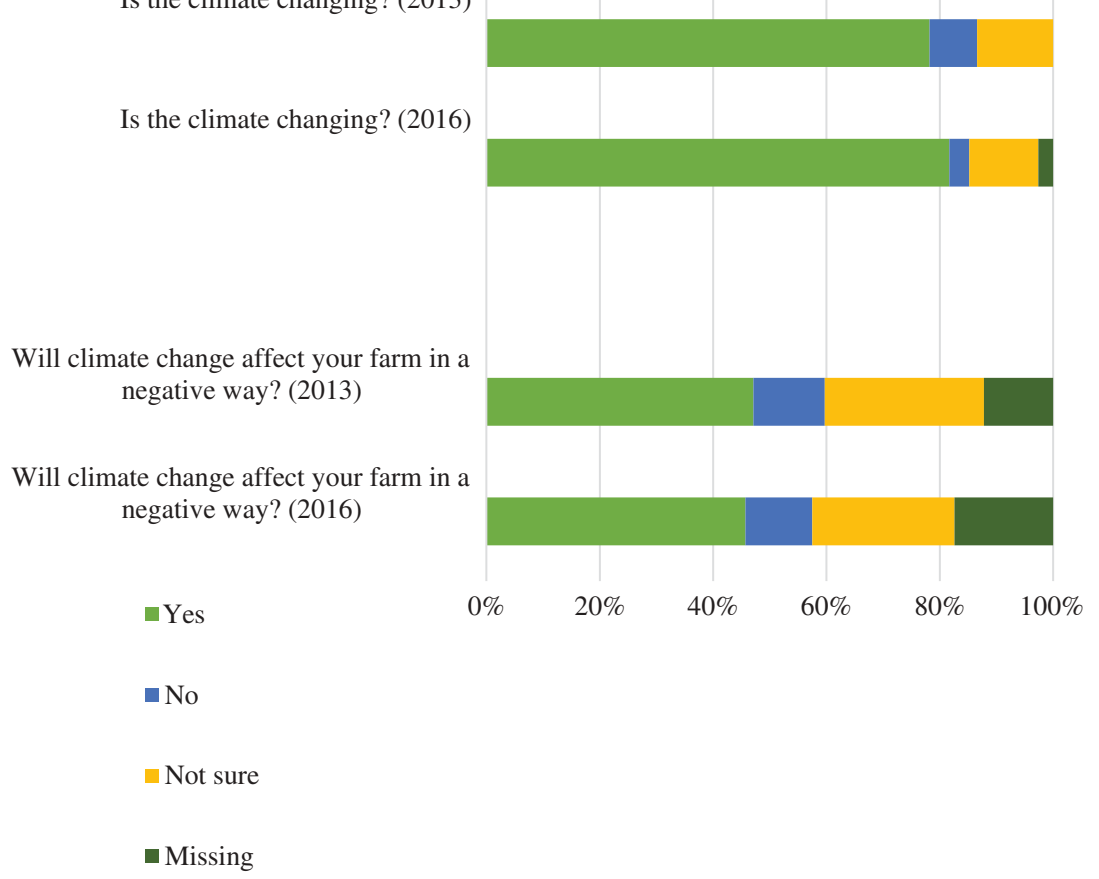

Figure 1. Farmer belief in climate change as reported in the 2013 and 2016 surveys.

$(87 \%, n=42)$. There were no statistically significant changes in farmer beliefs in climate change over the 3-year period. Three Wilcoxon signed ranks tests, which tested changes in individual farmers' perceptions of climate-related risks between the two, showed no significant shifts in farmer perceptions of the three types of climate-related risk examined (i.e., heavy rainfall, extreme temperatures, and drought).

\subsection{Evaluation of potential climate adaptation BMPs}

The 2013 survey asked farmers to report practices they used on their farms from the list of 20 preselected BMPs. Rotational grazing (42\% of respondents reported using it), insurance (44\%), timely manure incorporation (40\%), and conservation buffers (38\%) stand out as the most frequently reported. Through the interviews, we sought detailed information about farmer and agricultural advisor perceptions of these practices, as farmers and agricultural advisors were asked to evaluate only those BMPs they felt experienced with or that they were highly knowledgeable about. Respondents selected between two and nine practices to evaluate. We found that the farmers and agricultural advisors in our sample were in agreement about several practices that had potential to be classified as CCBMPs, indicated both by the scores given to these practices and by the number of respondents who selected these 


\section{A drought will have (2013):}

A drought will have (2016):

Extreme temperature will have (2013):
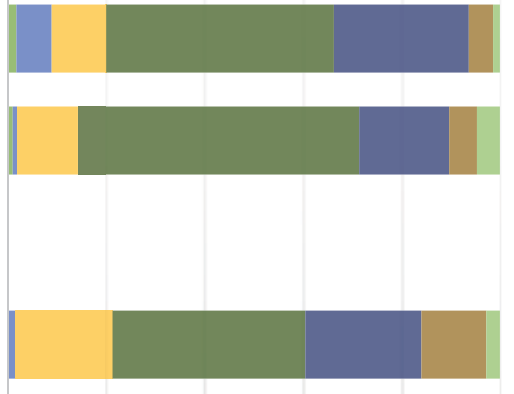

Extreme temperature will have (2016):

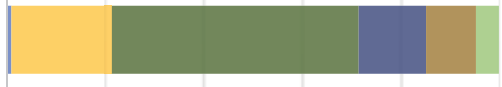

Heavy Rain will have (2013)

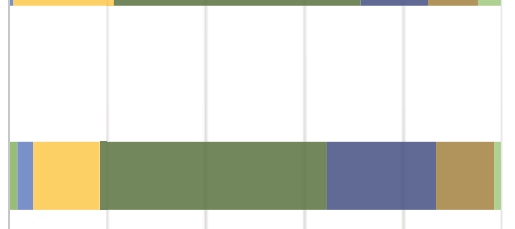

Heavy Rain will have (2016)

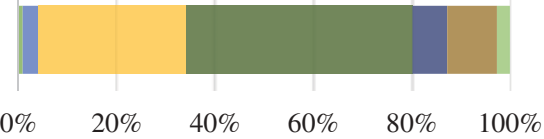

A strongly net positive impact on my farm

- A positive net impact on my farm

No net impact on my farm

- A negative net impact on my farm

- A strongly net negative impact on my farm

not sure

Missing

Figure 2. Farmer perceptions of climate-related risks and their potential impacts (2013 and 2016 surveys).

practices to evaluate (see Figure 3). These included rotational grazing $(n=12)$, cover crops $(n=11)$, and hoop houses (unheated greenhouses, also called high tunnels, $n=12$ ).

While some practices were ranked positively across most attributes (e.g., rotational grazing and cover crops), practices were not universally ranked highly in all three categories (financial, ecological, and social). This indicates that potential climate adaptation BMPs have strengths and weaknesses, or trade-offs associated with them (see Figures 4-6). For example, hoop houses were ranked highly in terms of their positive impact on financial measures such as production and yield, alignment of supply and demand, diversification of products and product quality. However, across all respondents who evaluated hoop houses, these structures were ranked highly in some ecological attributes (drought management, management of excess water, and responses to changing average temperatures), and lower in others. Their combined ecological score suffered due to low rankings for impact on 


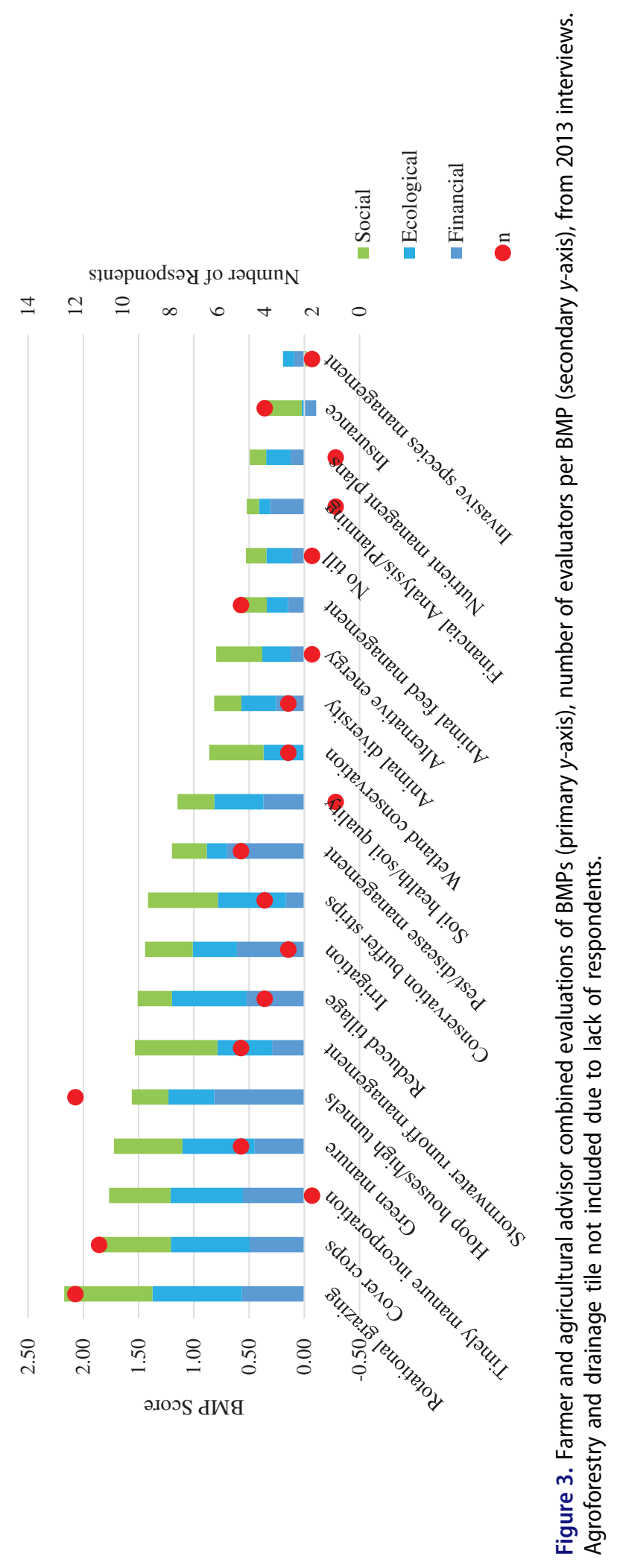


biodiversity, soil conservation, and visual impact on the landscape. This was true in participants' evaluation of social attributes of hoop houses as well. Hoop houses were ranked positively for acceptability to peers (other farmers) and their contributions to preserving agricultural land use (because of economic benefits and contributions they make toward farm business viability). However, they were ranked negatively in some attribute categories. Six out of eight farmers and three out of four agricultural advisors who evaluated the hoop houses gave them negative scores on "landscape appearance." Four out of eight farmers and one out of four agricultural advisors who evaluated the same practice gave hoop houses a negative score on "impact on neighbor relations."

Cronbach alphas for each attribute category used 17 valid responses each, and were as follows: ecological $(\alpha=0.60)$, financial $(\alpha=0.54)$, and sociocultural $(\alpha=0.68)$. Variation in attribute category scores is demonstrated in Figures 4-6. These figures show that there are no differences in how farmers and agricultural advisors evaluate potential climate adaptation BMPs based on attribute categories. Independent $t$-tests indicate that farmers and agricultural advisors in this study do not show statistically significant perceptions regarding BMP performance in each attribute category (i.e., financial, ecological, and social) (see supplemental material, Table S3). We acknowledge that examining attribute categories in place of the attributes themselves may obscure important differences. Common assessments of climate adaption BMPs between farmers and agricultural advisors were also reinforced in the interview transcripts, specifically those instances where farmers and
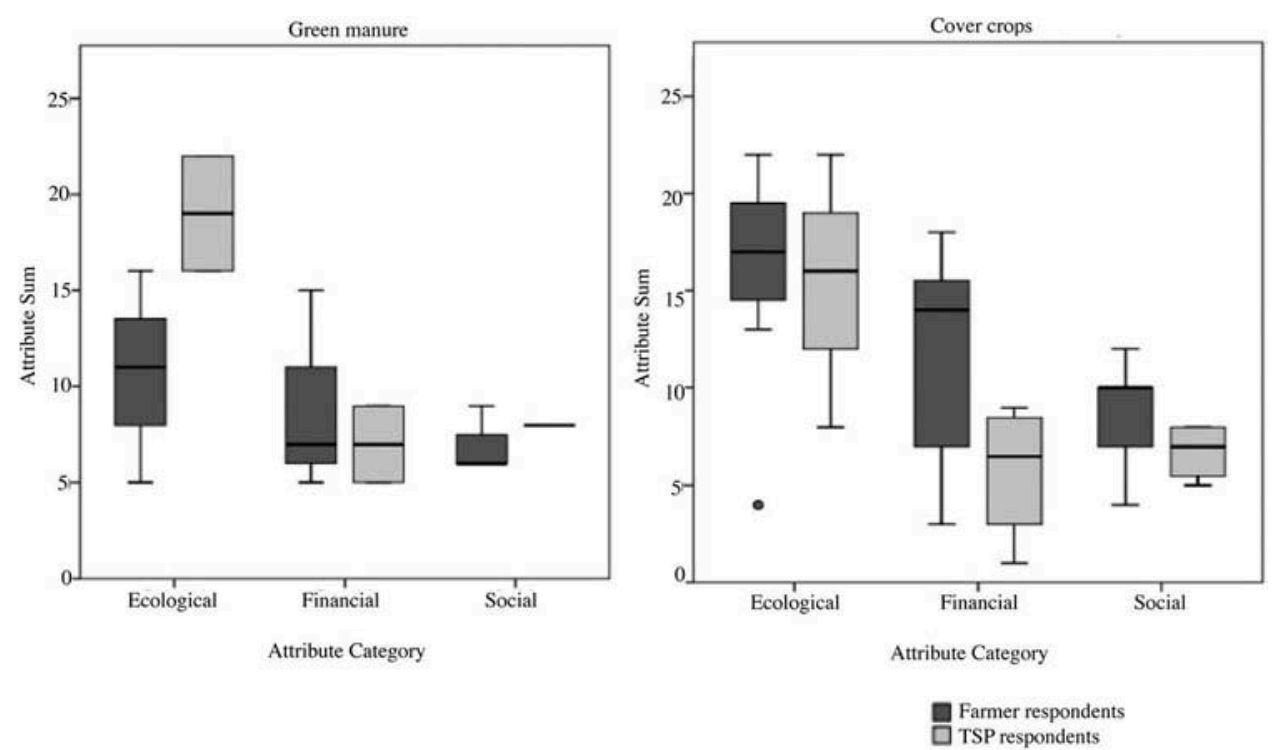

Figure 4. Farmer and agricultural advisor evaluation of green manure and cover crops (from 2013 interviews). 

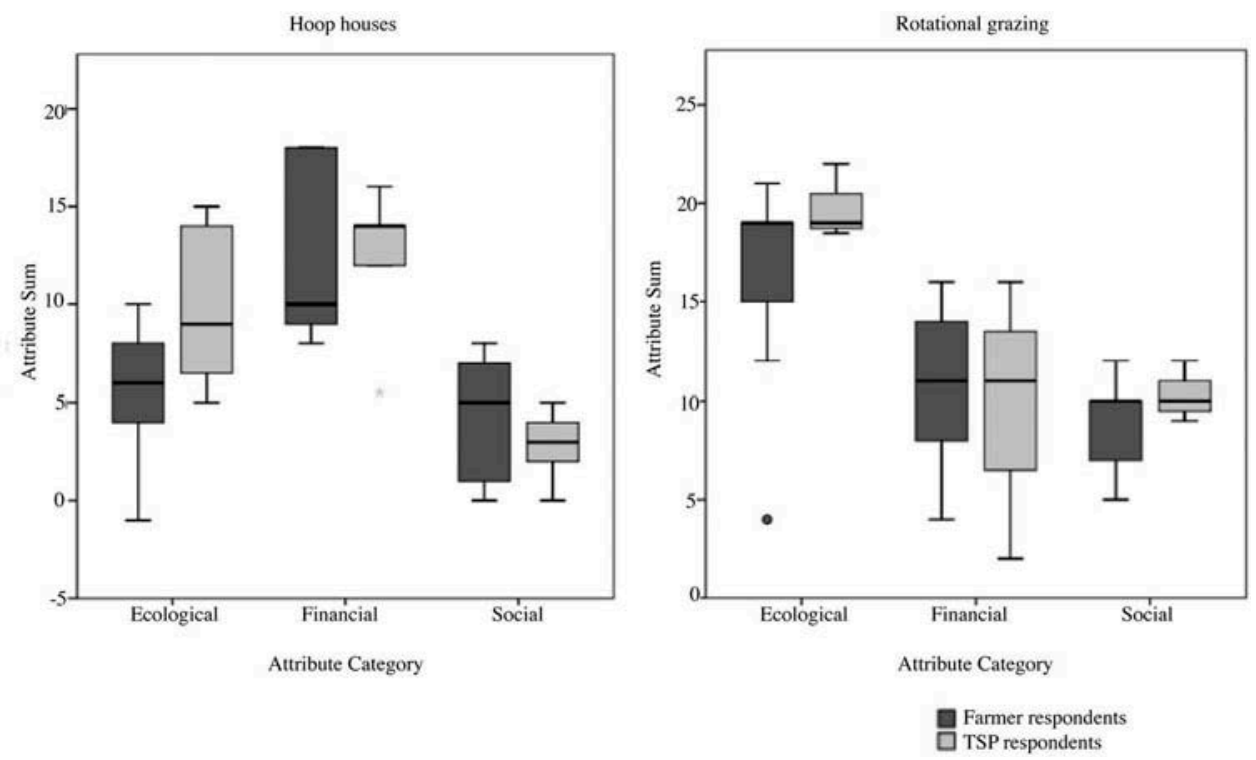

Figure 5. Farmer and agricultural advisor evaluation of hoop houses and rotational grazing (from 2013 interviews).

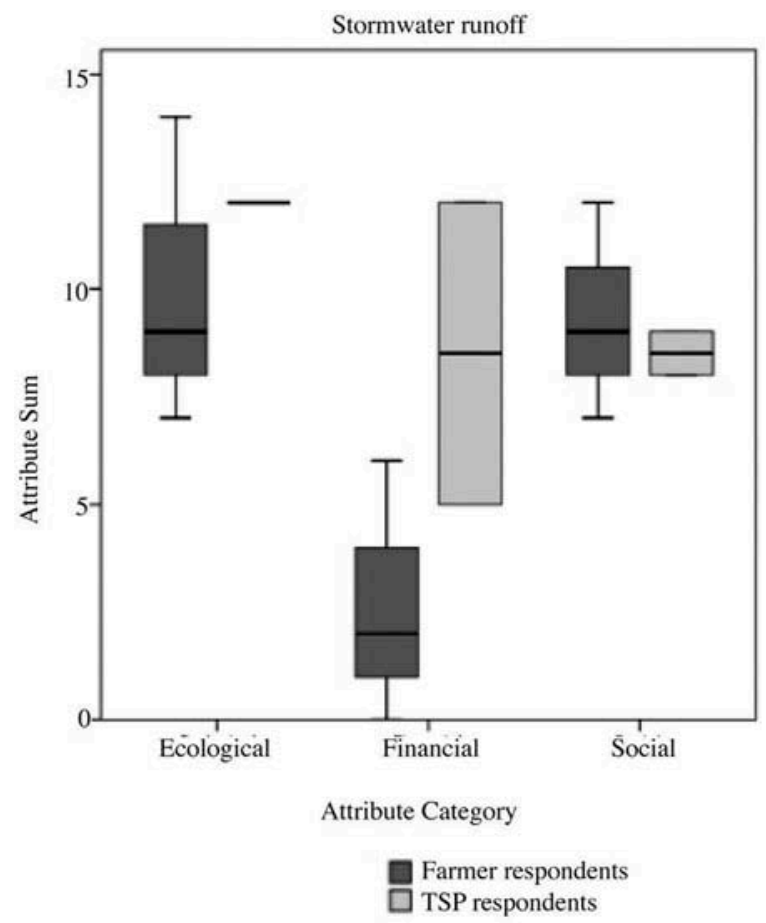

Figure 6. Farmer and agricultural advisor evaluation of stormwater runoff (from 2013 interviews). 
Table 3. Direct quotes from farmers and agricultural advisors (from interviews) showing overlap in BMP assessments.

\begin{tabular}{|c|c|c|}
\hline BMP & Example of farmer perspective & Example of agricultural advisor perspective \\
\hline Hoop houses & $\begin{array}{l}\text { We now have two hoop houses that we have } \\
\text { put up in the past } 5 \text { years... people are } \\
\text { seeing it as a response to erratic weather, } \\
\text { because you can control it better inside... } \\
\text { We think about setting up more. }\end{array}$ & $\begin{array}{l}\text { Even if you are on upland soils, if you are } \\
\text { getting } 30 \text { inches of rain in a month, it is } \\
\text { just leeching (nutrients) out. How do you } \\
\text { address that? You need a lot more } \\
\text { greenhouses and things like that. }\end{array}$ \\
\hline $\begin{array}{l}\text { Green } \\
\text { manure } \\
\text { and cover } \\
\text { crops }\end{array}$ & $\begin{array}{l}\text { One year we will cover crop, the next year } \\
\text { we will seed, and the year after we will cover } \\
\text { crop ...I am really trying to use cover crops } \\
\text { as a main source of nutrients and nitrogen } \\
\text { but that is hard to do. }\end{array}$ & $\begin{array}{l}\text { Cocktail cover cropping is changing } \\
\text { production agriculture, sweeping across the } \\
\text { Midwest and West. It is exploding. I've } \\
\text { never seen anything grow this fast ... Right } \\
\text { now the buzz is cover crops. }\end{array}$ \\
\hline $\begin{array}{r}\text { Rotational } \\
\text { grazing }\end{array}$ & $\begin{array}{l}\text { We've seen pastures that UVM extension } \\
\text { people said were un-grazable turn into some } \\
\text { of the best pasture ...it's because of } 3 \text { years } \\
\text { of intensive (rotational) grazing. When } \\
\text { animals are managed appropriately they can } \\
\text { actually have a positive impact on land. }\end{array}$ & $\begin{array}{l}\text { Grass-based systems are so much more } \\
\text { resilient, that's all. If we could scale up } \\
\text { some of our grass-based dairies it would be } \\
\text { great, because they're so much more } \\
\text { resilient than an annual-based, } \\
\text { conventional dairy. }\end{array}$ \\
\hline
\end{tabular}

agricultural advisors spoke of their perceptions of particular practices. Table 3 provides a selection of farmer and agricultural advisors quotes that shows overlap in these perspectives.

Practices that were not highly ranked can also tell us important things about the perceptions of these practices held by farmer and agricultural advisors in our sample. Although relatively few interview participants chose to evaluate insurance $(n=4)$ as a potential climate adaptation BMP, it was discussed in depth in the interviews and serves as a good example of how practices have opportunity costs associated with them. Farmers expressed that they felt as though insurance was a necessary part of doing business, and offered some protection while also decreasing their willingness and ability to diversify. Discussion of insurance during the interviews focused on liability insurance, with a notable absence of discussion about crop insurance. For example, one diversified farmer described their relationship to her liability insurance and policy:

There is a big story behind this farm and insurance. Insurance I guess is a good thing, although sometimes I feel like it's a scam. We are a farm at farmer's markets, so we have to have insurance at all times. We cannot have a lapse of insurance at any time in this industry.

It has been shown that insurance is a useful tool in protecting farms from crop losses associated with extreme weather, and participation in crop insurance programs has increased in the United States over the past 20 years (Glauber 2013). According to the USDA Risk Management Agency (RMA), the crops insured in 2016 included commodity crops such as apples, soybeans, corn, forages, and wheat (USDA RMA 2017). The demand for insurance is likely to increase as impacts from climate change 
negatively affect agriculture. However, farms that are highly diversified are less likely to purchase crop insurance; diversification is seen as an alternative approach to limiting climate-related risk (Falco et al. 2014).

Diversification of farm products and practices was a BMP not evaluated in this analysis, but has been shown to be an important adaptation practice in the context of climate change (Bulla and Steelman 2016; Marshall et al. 2016; Schattman et al., 2015a). Barbeiri et al. (2008) found that there was a clear association between farm diversification and how they marketed their products, with more diversified operations leaning toward direct market options such as farmers markets, and subscription programs, and less-diversified farms tending toward wholesale markets. Despite its small size, Vermont is seventh in the nation for top sales of direct marketed agricultural products (\$250 million in 2015) (USDA-NASS 2016), which corresponds with the popularity of highly diversified farms and local food consumption (Sawyer et al. 2013).

\section{Discussion}

Based on our survey results, the percentage of Vermont farmers who responded to our surveys who believe that the climate is changing is high (average of $80 \%$ for both years) when compared with projected levels of belief in global warming in the general Vermont population (68\%), and a national average of $63 \%$ projected using the Yale Climate Opinion Map (Howe et al. $2015)<\mathrm{AQ}>$ Please check this sentence for clarity. $</ \mathrm{AQ}>$. The percentage of farmers in our study who report believing in climate change is also greater than the percentage of farmers who believe the same in other parts of the United States and other high-income countries. Prokopy et al.'s (2015a) review of six studies that included farmer belief in climate change showed that $54 \%$ of farmers in California and $66 \%$ of farmers in the midwestern United States believe that the climate is changing. This could be skewed by the difference between how the six studies asked farmers about their perceptions (using a five-point Likert scale) versus how our study posed the questions (yes, no, not sure). Communication with one of the study's authors leads us to believe that if farmers in California who reported being "neutral" in their belief of climate change were added to those who reported that climate change was "likely" or "very likely," the percentage would be closer to the percentage of Vermont farmers that reported "yes" to their belief in climate change in our study (Niles, personal communication).

This illustrates the difficulty in gaining a clear understanding about how differences in perceptions about climate change and climate-related risk play out across the United States. We found that there is a lack of coordination of research instruments, including variation in language (e.g., terminology such as climate change, global warming, and extreme weather) and question 
format (e.g., qualitative vs. quantitative approaches, yes/no choices vs. Likert scales). Despite the difficulties in comparing study results, our findings suggest that there may be regional differences across the United States when it comes to farmer perceptions of climate-related agricultural risks. In contrast to the large percentage of respondents to our survey who believe climate change poses a significant risk to their farm (47\% in 2013 and $46 \%$ in 2016), the same review by Prokopy et al. (2015a) reported that studies conducted in the midwestern United States, California, Scotland, New Zealand, and Australia all found that the majority of farmers do not believe that climate change poses a significant threat to local agriculture. This difference in risk perception has implications for what types of adaptation strategies are likely to be adopted.

The debate about whether personal experience with extreme weather events influences climate belief, willingness to adopt adaptation practices, or farmer perception of risk is ongoing. While some argue for the direct connection between extreme events and climate change belief and willingness to adapt (Niles and Mueller 2016; Spence et al. 2011), a recent study of farmers in the midwestern United States indicates that the relationship between personal experience and belief is more nuanced. Specifically, the connection between extreme events and climate change belief and willingness to adapt is not clear, but the connection between extreme events and risk perception is more so (Carlton et al. 2016). Our work does not support either of these propositions, as change in farmer belief in climate change and perceptions of climate-related risk did not change significantly over the 3 -year period. This was true despite increases in average annual precipitation in Vermont (established by 1901-2000 rainfall data) every year since 2001, with 2011 boasting the highest recorded annual rainfall since 1895 (NOAA 2016). Recent studies have shown an uptick in heavy precipitation in the northeast region; the most recent U.S. National Climate Assessment states that changes in wettest day of the year are anticipated to follow trends in average precipitation (Kunkel et al. 2013; Walsh, Wuebbles, and Hayhoe 2014). Much of the state, and many farmers in Vermont, were negatively impacted by Tropical Storm Irene (which occurred in 2011), which caused significant damage to public infrastructure, private property, and farms (Galford et al. 2014). While still above average, annual precipitation in 2012-2015 was much closer to state norms (NOAA 2016). When the second survey was deployed, farmers were experiencing the beginning of a drought that would continue through much of the 2016 growing season. Despite the impact that these climate-related events had and continue to have on farmers' crops, livestock, and livelihoods, we did not find evidence that these personal experiences shifted farmer belief in climate change or perceptions of climate-related risk. 
The farm practices evaluated by farmers and agricultural advisors through the interviews are those that our interview participants believe have the most promise for limiting climate-related risks on their own farms. Through the interviews, we were able to compare how respondents believe that potential climate adaptation BMPs perform across three attribute categories, making it clear that all practices have trade-offs. The concept of trade-offs related to environmental and livelihood (production) outcomes in agroecological contexts has been previously established (Lovell et al. 2010; Méndez et al. 2012), and our study supports that sociocultural trade-offs are an additional important consideration. Considering the lack of studies that have addressed BMP efficacy in all attribute categories under forecasted climate scenarios, the endemic evaluations of our farmer informants point the way toward an important suite of practices. These practices should be evaluated rigorously for continued performance considering new climatic regimes.

Within our sample of farmers and agricultural advisors, we did not establish significant differences in how these groups scored attribute categories of BMPs. This implies that, in Vermont, outreach and education that focuses on climate change information and risk assessment, which is targeted toward farmers and agricultural advisors, does not necessarily need to be designed with completely different content, but can take advantage of the likely overlap of common beliefs and levels of knowledge held by farmers and agricultural advisors. Focusing on agricultural advisors as conduits of scientific information, and differentiating between agricultural advisors who work with farmers in different topic areas (such as production, financial planning, crisis counseling), is an area of great opportunity. With this field of inquiry, it would be wise to differentiate between agricultural advisors who already use climate change in their technical assistance activities and those who do not. For example, Haigh et al. (2015) have shown that agricultural financial advisors are reluctant to include climate-related risk factors in their advising strategies when compared with peers who advise farmers on production issues. Agricultural advisors may not include climate-related information into their outreach and education efforts for a variety of reasons, including lack of confidence in the subject matter, their own skepticism or farmers' skepticism, or lack of usable information. Monroe et al. (2015) found that while agricultural advisors in the southeastern United States were well-positioned to deliver climate change education to farmers, many did not want to or did not feel able to do so. Despite this potential underdevelopment of agricultural advisors' ability or willingness to incorporate climate change into their outreach (as appropriate), trusted advisors who are embedded in agricultural networks are potentially the best positioned individuals to communicate climate change-related information between the scientific and farmer community. 


\subsection{Limitations of our study}

When examining farmer and agricultural advisor evaluations of potential climate adaptation BMPs, our analysis treated financial, ecological, and social attribute categories as independent from one another. In real life, interactions between attribute categories are ongoing: financial attributes impact and are impacted by social and ecological attributes, etc. We addressed this when determining the significance of independent $t$-tests by setting the alpha threshold at 0.05 . Additionally, we acknowledge that attribute category scores used to perform $t$-tests were averages drawn from the evaluation of many attributes, and that an examination of these individual attributes may lead to observable differences missed by our analysis.

In analyzing the scores given to BMPs by both farmers and agricultural advisors, we asked respondents to score an attribute as "0" if they did not have sufficient information about the attribute or they believed the impact to be neutral. In the analysis of these data, we realized that this approach decreased the data's richness and obscured our findings. If the study were to be replicated, we would suggest asking respondents to assign "0"s to attributes only if there was no perceived impact, and to not score the attribute if there was insufficient information with which to judge the impact. The final scores could be weighted to account for the number of attributes left blank, better representing both perceptions of the BMPs and level of knowledge of the respondent.

\section{Conclusion}

This study demonstrated that the majority of the farmers who responded to our survey believe that the climate is changing, and that climate change will likely impact their farms in a negative manner. Most farmer respondents also believed that three likely impacts of climate change (heavy rain events, increasing extreme temperatures, and drought) in the northeastern United States will have negative or very negative net impacts on their farms. There is no evidence from our study to support the link between extreme events, such as increases in average and extreme precipitation or drought, and changes in farmer belief in climate change or perceptions of climate-related risk. Farmers in this area already employ BMPs that can potentially be categorized as climate adaptation BMPs, pending further on-the-ground investigations. Farmer and agricultural advisor endemic evaluations of potential climate adaptation BMPs confirm each other, and can be used to guide future research that addresses efficacy of these practices to mitigate climate-related risks.

The results of this investigation make important contributions to our understanding of farmer perceptions of climate-related risk, minimizing 
risk through potential climate adaptation BMPs, and alignment of farmer and agricultural advisor views of these practices. We also open further lines of inquiry that should be explored. First, there is a need for additional studies to address farmer willingness to adopt climate adaptation BMPs. By extension, the relationships between risk perception, intention to adopt climate adaptation BMPs, and actual adoption of practices should be studied across diverse regions in the United States, as our research does not confirm the findings of previous studies. Second, endemic evaluation of a smaller set of potential climate adaptation BMPs through a larger representative sample of northeastern U.S. farmers and agricultural advisors is needed to clarify how these groups may score specific BMP attributes. This would further our understanding of the strengths and weaknesses of these practices in a greater diversity of on-farm settings. Third, by reducing the list of potential climate adaptation BMPs, we can now focus on evaluation of how these practices perform under different climate change scenarios. In the context of climate change, a broad set of variables should be included when examining efficacy, including soil type, erosion potential, cropping system, and value of crops, as well as regulatory and incentive programs, and other factors that influence the feasibility of practices. Sociocultural attributes should be integrated into these assessments. An assessment of this sort, combined with climate forecast models, should be applied to the whole northeast region of the United States, thereby deepening our understanding of the challenges and opportunities ahead for agriculture in this region.

\section{Acknowledgments}

We thank the farmers and agricultural advisors who participated in this project, and the Vermont Agricultural Resilience in a Changing Climate team for their contributions to the 2013 and 2016 farmer survey, including Christopher Koliba, David Conner, E. Carol Adair, Stephanie Hurley, Linda Berlin, Juan Alvez, Joshua Faulkner, Kimberly Hagan, Martha Caswell, Katherine Westdijk, Heather Darby, and Yu-Shoiu Tsai. Florence Becot, Gary Keogh, Hannah M. Aitken, and Alan Howard assisted with data analysis. Meredith Niles and two anonymous reviewers provided valuable feedback on earlier drafts of this manuscript.

\section{ORCID}

Rachel E. Schattman (D) http://orcid.org/0000-0001-7177-3914

\section{References}

Adger, N. W. 2006. Vulnerability. Global Environmental Change 16(3):268-81. doi:10.1016/j. gloenvcha.2006.02.006. 
Adger, N. W., N. W. Arnell, and E. L. Tompkins. 2005. Successful adaptation to climate change across scales. Global Environmental Change 15(2):77-86. doi:10.1016/j. gloenvcha.2004.12.005.

Adger, N. W., S. Dessai, M. Goulden, M. Hulme, I. Lorenzoni, D. R. Nelson, L. O. Naess, J. Wolf, and A. Wreford. 2008. Are there social limits to adaptation to climate change? Climatic Change 93(3-4):335-54. doi:10.1007/s10584-008-9520-z.

Akerlof, K., E. W. Maibach, D. Fitzgerald, A. Y. Cedeno, and A. Neuman. 2013. Do people 'personally experience' global warming, and if so how, and does it matter? Global Environmental Change 23(1):81-91. doi:10.1016/j.gloenvcha.2012.07.006.

Arbuckle, J. G., J. Hobbs, A. Loy, L. W. Morton, L. S. Prokopy, and J. Tyndall. 2014. Understanding corn belt farmer perspectives on climate change to inform engagement strategies for adaptation and mitigation. Journal of Soil and Water Conservation 69(6):505-16. doi:10.2489/jswc.69.6.505.

Arbuckle, J. G., L. S. Prokopy, T. Haigh, J. Hobbs, T. Knoot, C. Knutson, A. Loy. et al. 2013. Climate change beliefs, concerns, and attitudes towards adaptation and mitigation among farmers in the midwestern United States. Climatic Change 117:943-50. doi:10.1007/s10584013-0707-6.

Barbieri, C., E. Mahoney, and L. Butler. 2008. Understanding the nature and extent of farm and ranch diversification in North America. Rural Sociology 73(2):205-29. doi:10.1526/ 003601108784514543.

Barnes, A. P., and L. Toma. 2012. A typology of dairy farmer perceptions towards climate change. Climatic Change 112:507-22. doi:10.1007/s10584-011-0226-2.

Baumgart-Getz, A., L. S. Prokopy, and K. Floress. 2012. Why farmers adopt best management practice in the United States: A meta-analysis of the adoption literature. Journal of Environmental Management 96(1):17-25. doi:10.1016/j.jenvman.2011.10.006.

Betts, A. K. 2011. Vermont climate change indicators. Weather, Climate, and Society 3 (2):106-15. doi:10.1175/2011WCAS1096.1.

Boeije, H. 2002. A purposeful approach to the constant comparative method in the analysis of qualitative interviews. Quality and Quantity 36:391-409. doi:10.1023/A:1020909529486.

Brody, S. D., and S. Zahran. 2008. Examining the relationship between physical vulnerability and public perceptions of global climate change in the United States. Environment and Behavior 40(1):72-95. doi:10.1177/0013916506298800.

Brooks, N. 2003. Vulnerability, risk and adaptation: A conceptual framework. Norwich, UK: Tyndall Centre for Climate Change Research. papers2://publication/uuid/D2016620-F4DE4C0A-BE4B-78E8F2701438.

Bulla, B., and T. Steelman. 2016. Farming through change: Using photovoice to explore climate change on small family farms. Agroecology and Sustainable Food Systems 40 (1):1106-32. doi:10.1080/21683565.2016.1225623.

Carlisle, L. 2016. Factors influencing farmer adoption of soil health practices in the United States: A narrative review. Agroecology and Sustainable Food Systems 40(6):583-613. doi:10.1080/21683565.2016.1156596.

Carlton, J. S., A. S. Mase, C. L. Knutson, M. C. Lemos, T. Haigh, D. P. Todey, and L. S. Prokopy. 2016. The effects of extreme drought on climate change beliefs, risk perceptions, and adaptation attitudes. Climatic Change 135(2):211-26. doi:10.1007/s10584-0151561-5.

Casanova-Pérez, L., J. P. Martínez-Dávila, S. López-Ortiz, C. Landeros-Sánchez, and G. López-Romero. 2016. Sociocultural dimension in agriculture adaptation to climate change. Agroecology and Sustainable Food Systems 40(8):848-62. doi:10.1080/ 21683565.2016.1204582. 
Charmaz, K. 2005. Grounded theory in the 21st century: Applications for advancing social justice studies. In The sage handbook of qualitative research, ed. Y. S. Denzin, and N. K. Lincoln, 507-35, 3rd ed. Thousand Oaks, CA: Sage Publications.

Chatrchyan, A. M., R. C. Erlebacher, N. T. Chaopricha, J. Chan, D. Tobin, and S. B. Allred. 2017. United States agricultural stakeholder views and decisions on climate change. Wiley Interdisciplinary Reviews: Climate Change e467:1-21.

Dunlap, R. E., A. M. McCright, and J. H. Yarosh. 2016. The political divide on climate change: Partisan polarization widens in the U.S. Environment: Science and Policy for Sustainable Development 58(5):4-23. doi:10.1080/00139157.2016.1208995.

Eakin, H., A. York, R. Aggarwal, S. Waters, J. Welch, C. Rubiños, S. Smith-Heisters, C. Bausch, and J. M. Anderies. 2016. Cognitive and institutional influences on farmers' adaptive capacity: Insights into barriers and opportunities for transformative change in central Arizona. Regional Environmental Change 16(3):801-14. doi:10.1007/s10113-0150789-y.

Falco, S. D., F. Adinolfi, M. Bozzola, and F. Capitanio. 2014. Crop insurance as a strategy for adapting to climate change. Journal of Agricultural Economics 65(2):485-504. doi:10.1111/ 1477-9552.12053.

Francis, C., G. Lieblein, S. Gliessman, T. A. Breland, N. Creamer, R. Harwood, L. Salomonsson, et al. 2003. Agroecology: The ecology of food systems. Journal of Sustainable Agriculture 22(3):99-118. doi:10.1300/J064v22n03.

Frumhoff, P. C., J. J. McCarthy, J. M. Melillo, S. C. Moser, D. J. Wuebbles, C. Wake, and E. Spanger-Siegfried. 2007. An integrated climate change assessment for the northeast United States. Mitigation and Adaptation Strategies for Global Change 13(5-6):419-23. doi:10.1007/s11027-007-9138-x.

Fuhrer, J. 2003. Agroecosystem responses to combinations of elevated CO2, ozone, and global climate change. Agriculture, Ecosystems \& Environment 97:1-20. doi:10.1016/S0167-8809 (03)00125-7.

Galford, G. L., A. Hoogenboom, S. Carlson, S. Ford, J. Nash, E. Palchak, S. Pears, K. Underwood, and D. Baker. 2014. Considering Vermont's future in a changing climate: The first Vermont climate assessment. Burlington, Vermont: The Gund Institute for EcologicalEconomics.

Glaser, B. G., and A. L. Strauss. 1967. The discovery of grounded theory: Strategies for qualitative research. In Observations, Vol. 1, ed. B. Glaser, and A. N. Strauss. Chicago: Aldine. doi:10.2307/2575405.

Glauber, J. W. 2013. The growth of the federal crop insurance program, 1990-2011. American Journal of Agricultural Economics 95(2):482-88. doi:10.1093/ajae/aas091.

Gliessman, S. R. 2015. Agroecology: The ecology of sustainable food systems, 3rd ed. Boca Raton, FL: CRC Press/Taylor \& Francis.

Guilbert, J., A. K. Betts, D. M. Rizzo, B. Beckage, and A. Bomblies. 2015. Characterization of increased persistence and intensity of precipitation in the northeastern United States. Geophysical Research Letters 42(6):1888-93. doi:10.1002/2015GL063124.

Haigh, T., L. W. Morton, M. C. Lemos, C. Knutson, L. S. Prokopy, Y. J. Lo, and J. Angel. 2015. Agricultural advisors as climate information intermediaries: Exploring differences in capacity to communicate climate. Weather, Climate, and Society 7(1):83-93. doi:10.1175/ WCAS-D-14-00015.1.

Hassinger, E. 1959. Stages in the adoption process. Rural Sociology 24(1):52-53.

Horton, R., G. Yohe, W. Easterling, R. Kates, M. Ruth, E. Sussman, A. Whelchel, and D. Wolfe. 2014. Climate change impacts in the United States: Northeast. In Climate change impacts in the United States: The third national climate assessment, ed. J. M. Melillo, T. C. 
Richmond, and G. W. Yohe, 371-95. U.S. Global Change Research Program. doi:10.7930/ J0SF2T3P.On.

Howe, P. D., M. Mildenberger, J. R. Marlon, and A. Leiserowitz. 2015. Geographic variation in opinions on climate change at state and local scales in the USA. Nature Climate Change 5:596-603. doi:10.1038/nclimate2583.

Hyland, J. J., D. L. Jones, K. A. Parkhill, A. P. Barnes, and A. P. Williams. 2016. Farmers' perceptions of climate change: Identifying types. Agriculture and Human Values 33(2):1-17. doi:10.1007/s10460-015-9608-9.

IBM. 2012. IBM SPSS advanced statistics 20 In IBM. doi:10.1080/02331889108802322.

HyperRESEARCH3.5.2. Computer Software. ResearchWare Inc. 2013. Randolf, Massachusetts, USA.

IPCC. 2007. Appendix I: Glossary. Climate change 2007: Impacts, adaptation and vulnerability. Contribution of working group II to the fourth assessment report of the intergovernmental panel on climate change. doi:10.1016/0197-2456(95)90487-5

Just, D. R., S. Wolf, and D. Zilberman. 2003. Principles of risk management service relations in agriculture. Agricultural Systems 75(2-3):199-213. doi:10.1016/S0308-521X(02)00065-3.

Kunkel, K. E., L. E. Stevens, S. E. Stevens, L. Sun, E. Janssen, D. Wuebbles, J. Rennells, A. DeGaetano, and J. G. Dobson. 2013. Regional climate trends and scenarios for the U.S. national climate assessment. Part 1. Climate of the northeast U.S. Washington, DC: U.S. Department of Commerce, National Oceanic and Atmospheric Administration. NOAA Technical Report NESDIS, 142-1.

Leiserowitz, A., E. Maibach, C. Roser-Renouf, G. Feinberg, and S. Rosenthal. 2015. Climate change in the American mind. In Yale University and George Mason University, New Haven, CT: Yale Program on Climate Change Communication. September 1-47.

Lopez, R., N. Plesha, B. Campbell, and C. Laughton. 2015. Northeast economic engine: Agriculture, forest products, and commercial fishing. Enfield, CT: Farm Credit East.

Lovell, S. T., S. DeSantis, C. Nathan, M. B. Olson, V. E. Méndez, H. Kominami, D. L. Erickson, K. S. Morris, and W. B. Morris. 2010. Integrating agroecology and landscape multifunctionality in Vermont: An evolving framework to evaluate the design of agroecosystems. Agricultural Systems 103(5):327-41. doi:10.1016/j.agsy.2010.03.003.

Macdonald, J. M., P. Korb, and R. A. Hoppe. 2013. Farm size and the organization of U.S. crop farming. Washington, DC: United States Service. http://www.ers.usda.gov/media/1156726/ err152.pdf.

Marshall, N. A., S. Crimp, M. Curnock, M. Greenhill, G. Kuehne, Z. Leviston, and J. Ouzman. 2016. Some primary producers Are more likely to transform their agricultural practices in response to climate change than others. Agriculture, Ecosystems \& Environment 222:38-47. doi:10.1016/j.agee.2016.02.004.

Mase, A. S., B. M. Gramig, and L. S. Prokopy. 2016. Climate change beliefs, risk perceptions, and adaptation behavior among midwestern U.S. crop farmers. Climate Risk Management 15:8-17. doi:10.1016/j.crm.2016.11.004.

Mase, A. S., and L. S. Prokopy. 2013. Unrealized potential: A review of perceptions and use of weather and climate information in agricultural decision making. Weather, Climate, and Society 6(1):47-61. doi:10.1175/WCAS-D-12-00062.1.

Méndez, V. E., S. Castro-Tanzi, K. Goodall, K. S. Morris, C. M. Bacon, P. Läderach, W. B. Morris, and M. U. Georgeoglou-Laxalde. 2012. Livelihood and environmental trade-offs of climate mitigation in smallholder coffee agroforestry systems. In Climate change mitigation and agriculture, ed. E. K. Wollenberg, A. Nihart, M. Tapio-Biström, and M. L. Grieg-Gran, 370-81. London: Earthscan. 
Monroe, M. C., R. R. Plate, D. C. Adams, and D. J. Wojcik. 2015. Harnessing homophily to improve climate change education. Environmental Education Research 21(2):221-38. doi:10.1080/13504622.2014.910497.

Morton, L. W., J. M. McGuire, and A. D. Cast. 2016. A good farmer pays attention to the weather. Climate Risk Management 15:18-31. doi:10.1016/j.crm.2016.09.002.

Myers, T. A., E. W. Maibach, C. Roser-Renouf, K. Akerlof, and A. A. Leiserowitz. 2013. The relationship between personal experience and belief in the reality of global warming. Nature Climate Change 3(4):343-47. doi:10.1038/nclimate1754.

National Sustainable Agriculture Coalition. 2014. 2012 census drilldown: Beginning farmers and ranchers. http://sustainableagriculture.net/blog/2012census-bfr-drilldown/.

Niles, M. T., M. Lubell, and V. R. Haden. 2013. Perceptions and responses to climate policy risks among California farmers. Global Environmental Change 23(6):1752-60. doi:10.1016/ j.gloenvcha.2013.08.005.

Niles, M. T., and N. D. Mueller. 2016. Farmer perceptions of climate change: Associations with observed temperature and precipitation trends, irrigation, and climate beliefs. Global Environmental Change 39:133-42. doi:10.1016/j.gloenvcha.2016.05.002.

NOAA. 2016. Climate at a glance. Climate monitoring, climate at a glance. National Oceanic and Atmospheric Administration. http://www.ncdc.noaa.gov/cag.

Prokopy, L. S., J. G. Arbuckle, A. P. Barnes, V. R. Haden, A. Hogan, M. T. Niles, and J. Tyndall. 2015a. Farmers and climate change: A cross-national comparison of beliefs and risk perceptions in high-income countries. Environmental Management 56:492-504. doi:10.1007/s00267-015-0504-2.

Prokopy, L. S., T. Haigh, A. S. Mase, J. Angel, C. Hart, C. Knutson, M. C. Lemos, et al. 2013. Agricultural advisors: A receptive audience for weather and climate information? Weather, Climate, and Society 5(2):162-67. doi:10.1175/WCAS-D-12-00036.1.

Prokopy, L. S., L. W. Morton, J. G. Arbuckle, A. S. Mase, and A. K. Wilke. 2015b. Agricultural stakeholder views on climate change: Implications for conducting research and outreach. Bulletin of the American Meteorological Society 96(2):181-90. doi:10.1175/BAMS-D-13-00172.1.

Risbey, J., M. Kandlikar, H. Dowlatabadi, and D. Graetz. 1999. Scale, context, and decision making in agricultural adaptation to climate variability and change. Mitigation and Adaptation Strategies for Global Change 4(2):137-65. doi:10.1023/A:1009636607038.

Roesch-McNally, G., J. G. Arbuckle, and J. C. Tyndall. 2017. What would farmers do? Adaptation intentions under a corn belt climate change scenario. Agriculture and Human Values 34(2):333-46. doi:10.1007/s10460-016-9719-y.

Rogers, E. M., and G. M. Beal. 1957. The importance of personal influence in the adoption of technological changes. Social Forces 36:329-35. doi:10.2307/2573971.

Sawyer, S., D. Hoffer, H. L. Jordan, and K. Perkins. 2013. Analysis of Vermont's food system: Understanding consumer demand. Montpelier, Vermont: The Vermont Sustainable Jobs Fund.

Schattman, R. E., H. M. Aitken, V. E. Méndez, and M. Caswell. 2015a. Climate change resilience on Vermont farms: A research report for service providers. Burlington, Vermont: The Agroecology and Rural Livelihoods Group.

Schattman, R. E., V. E. Méndez, K. Westdijk, M. Caswell, D. Conner, C. Koliba, and A. Zia. 2015b. Vermont agricultural resilience in a changing climate: A transdisciplinary and participatory action research (PAR) process. In Agroecology, ecosystems, and sustainability, ed. N. Benkeblia, et al., 326-46. Boca Raton, FL: CRC Press/Taylor \& Francis.

Schuldt, J. P., S. H. Konrath, and N. Schwarz. 2011. 'Global warming' or 'climate change'? Public Opinion Quarterly 75(1):115-24. doi:10.1093/poq/nfq073.

Singh, C., P. Dorward, and H. Osbahr. 2016. Developing a holistic approach to the analysis of farmer decision-making: Implications for adaptation policy and practice in developing countries. Land Use Policy 59:329-43. doi:10.1016/j.landusepol.2016.06.041. 
Spence, A., W. Poortinga, C. Butler, and N. F. Pidgeon. 2011. Perceptions of climate change and willingness to save energy related to flood experience. Nature Climate Change 1(4):4649. doi:10.1038/nclimate1059.

Strauss, A., and J. Corbin. 1990. Basics of qualitative research: Grounded theory procedures and techniques. In Basics of qualitative research techniques and procedures for developing grounded theory, ed. A. Strauss, and J. Corbin. Thousand Oaks, California: Sage.

Tobin, D., M. Janowiak, D. Hollinger, R. H. Skinner, C. Swanston, R. Steele, R. Radhakrishna, et al. 2015. Northeast and Northern forests regional climate hub assessment of climate change vulnerability and adaptation and mitigation strategies. Durham, NH: The United States Department of Agriculture Northeast Climate Hub.

United States Census Bureau. 2017. "Quick facts." Vermont quick facts. Accessed May 1, 2017. http://quickfacts.census.gov/qfd/states/08000.html.

USDA RMA. 2017. "Vermont crop insurance 2016 crop year." Risk managment agency state profile. Accessed May 1, 2017. https://www.rma.usda.gov/pubs/2017/stateprofiles/ver mont16.pdf.

USDA-NASS. 2012. "USDA-NASS census of agriculture." 2012 Census Publications. Accessed September 13, 2016. http://www.agcensus.usda.gov/Publications/2012/Full_Report/Census_by_ State/Vermont/.

USDA-NASS. 2013. "2012 census of agriculture: Vermont - Table 2. market value of agricultural products sold including landlord's share and direct sales." USDA Agriculture census - Vermont. Accessed May 17, 2015. http://www.agcensus.usda.gov/Publications/ 2012/Full_Report/Volume_1,_Chapter_1_State_Level/Vermont/st50_1_002_002.pdf.

USDA-NASS. 2015. Organic farming: Results from the 2014 organic survey. Washington, DC: Results from the 2014 Organic Survey. Accessed August 11, 2016. https://agcen sus.usda.gov/Publications/2012/Online_Resources/Highlights/Organics/2014_ Organic_Survey_Highlights.pdf.

USDA-NASS. 2016. Direct farm sales of food: Results from the 2015 local food marketing practices survey. Washington, DC. https://www.agcensus.usda.gov/Publications/2012/ Online_Resources/Highlights/Local_Food/LocalFoodsMarketingPractices_Highlights.pdf.

van der Linden, S. 2014. On the relationship between personal experience, affect and risk perception: The case of climate change. European Journal of Social Psychology 44(5):430-40. doi:10.1002/ejsp.2008.

Walsh, J., D. Wuebbles, and K. Hayhoe. 2014. Our changing climate. In Climate change impacts in the United States: The third national climate assessment, ed. J. M. Melillo, T. C. Richmont, and G. W. Yohe. U.S. Global Change Research Program. doi:10.7930/ J0KW5CXT.On.

Walthall, C. L., P. Hatfield, L. Backlund, E. Lengnick, M. Marshall, S. Walsh, S. Adkins, et al. 2012. Climate change and agriculture in the United States: Effects and adaptation. Washington, DC: United States Department of Agriculture Agricultural Research Service and the Climate Change Program Office.

Weider, K., and D. F. Boutt. 2010. Heterogeneous water table response to climate revealed by 60 years of ground water data. Geophysical Research Letters 37(24):10-15. doi:10.1029/ 2010GL045561.

Wiest, S. L., L. Raymond, and R. A. Clawson. 2015. Framing, partisan predispositions, and public opinion on climate change. Global Environmental Change 31:187-98. doi:10.1016/j. gloenvcha.2014.12.006.

Williams, M. S. 1958. Farmers' decisions in the use of fertilizer. Journal of Farm Economics 40 (5):1407-15. doi:10.2307/1235024. 